\title{
Interaction of the mechanism-based inactivator acetylene with ammonia monooxygenase of Nitrosomonas europaea
}

Correspondence
Ingo Schmidt
ingo.schmidt1@uni-bayreuth.de

Received 27 August 2008

Revised 15 October 2008

Accepted 15 October 2008

\author{
Stefan Gilch, ${ }^{1}$ Manja Vogel, ${ }^{1}$ Matthias W. Lorenz, ${ }^{2}$ Ortwin Meyer ${ }^{1}$ \\ and Ingo Schmidt ${ }^{1}$ \\ ${ }^{1}$ Department of Microbiology, University of Bayreuth, 95447 Bayreuth, Germany \\ ${ }^{2}$ Department of Animal Ecology, University of Bayreuth, 95447 Bayreuth, Germany
}

\section{INTRODUCTION}

Under oxic growth conditions Nitrosomonas europaea obtains energy by oxidation of ammonia via hydroxylamine to nitrite (Rees \& Nason, 1966; Hooper et al., 1997). The formation of hydroxylamine is catalysed by ammonia monooxygenase (AMO), which is thought to be a heteromultimeric copper protein encoded by the amoCAB operon (Dua et al., 1979; Anderson \& Hooper, 1983; Hyman \& Wood, 1985; Hyman \& Arp, 1993; Hooper et al., 1997; Chain et al., 2003); AmoA and AmoB were shown to co-purify (McTavish et al., 1993). Much of what is known about the catalytic activity of AMO originates from biochemical studies with intact bacteria or subcellular fractions, and was deduced from the very similar process of methane oxidation by (particulate) methane monooxygenase, (p)MMO. Acetylene $\left(\mathrm{C}_{2} \mathrm{H}_{2}\right)$ is an irreversible inhibitor of ammonia oxidation in Nitrosomonas (Dua et al., 1979; Anderson \& Hooper, 1983; Hyman \& Wood, 1985; Schmidt et al., 2001), but has no effect on hydroxylamine oxidation at concentrations sufficient to completely inactivate ammonia oxidation (Hynes \& Knowles, 1978). Acetylene has also been shown to be an inhibitor of other catalytically active monooxygenases (Hynes \& Knowles, 1978; Prior \& Dalton, 1985a; Zahn \& DiSpirito, 1996; Yeager et al., 1999). In AMO, acetylene binds to the $27 \mathrm{kDa}$ AmoA subunit (Hyman \& Arp, 1992). It was proposed that acetylene specifically inactivates catalytically active AMO as a result of an attempted oxidation of the triple bond of acetylene, forming a reactive intermediate that binds to an amino acid in or near the acetylene-activating site of AMO

Abbreviations: $\mathrm{AMO}$, ammonia monooxygenase; $\mathrm{pMMO}$ and $\mathrm{SMMO}$, particulate and soluble methane monooxygenase.
(Hynes \& Knowles, 1978; Hyman \& Wood, 1985). Even after denaturation of AMO, acetylene (or an acetylene derivative) remains bound to the AmoA subunit. Hence, acetylene has to bind directly to the protein, and binding to a metal atom can be excluded, because metals are liberated from proteins upon denaturation. Nevertheless, the mechanism of acetylene inactivation and its binding site in AMO are unknown.

Soluble and particulate methane monooxygenases (sMMO, pMMO) catalyse the oxidation of methane to methanol. Interestingly, sMMO, pMMO and AMO are able to oxidize both ammonia and methane, although ammonia supports growth only of nitrifiers and methane only that of methanotrophs (Bedard \& Knowles, 1989). As during ammonia oxidation, incorporation of one oxygen atom from $\mathrm{O}_{2}$ into a non-activated $\mathrm{C}-\mathrm{H}$ bond of methane (AMO: $\mathrm{N}-\mathrm{H}$ bond of ammonia) is catalysed by sMMO and pMMO and the second oxygen atom is reduced to water (Lipscomb, 1994). It was suggested that a dinuclear ferrous cluster in sMMO (Dalton et al., 1993) co-ordinates and activates oxygen. In pMMO a dinuclear or trinuclear copper centre (Lieberman \& Rosenzweig, 2005a, b; Lieberman et al., 2006; Chen et al., 2007; Chan \& Yu, 2008) or a dinuclear iron centre (Martinho et al., 2007) were proposed as catalytic centres. The resulting metal oxenoid species might then abstract a hydrogen atom from the substrate, leading to a deprotonated substrate intermediate and a metal-bound hydroxyl moiety. Rebinding of the hydroxyl could then yield the product (Nesheim \& Lipscomb, 1996). Because AMO and pMMO are similar on the genetic, protein and functional level such a reaction mechanism was also proposed for the copper-containing monooxygenase AMO (Hooper \& Terry, 1973; Stirling \& 
Dalton, 1977; Prior \& Dalton, 1985b; Shears \& Wood, 1985; Ensign et al., 1993; Zahn et al., 1996; Lieberman \& Rosenzweig, 2005a).

The present study started from the assumption that acetylene, or rather an activated acetylene derivative, binds to a specific amino acid of AmoA. We have identified ketene as the product of acetylene activation at AMO and His-191 in AmoA as the binding site for ketene.

\section{METHODS}

Organism and growth conditions. Stock cultures of N. europaea (ATCC 19718) were grown aerobically in 11 Erlenmeyer flasks containing $400 \mathrm{ml}$ mineral medium (Schmidt \& Bock, 1997). Cultures were grown in the dark at $28{ }^{\circ} \mathrm{C}$ with shaking at 50 r.p.m. Cultures in the late exponential growth phase were used to inoculate a 301 fermenter (Braun). Biomass was produced under discontinuous conditions with 201 mineral medium supplemented with $50 \mathrm{mM}$ $\mathrm{NH}_{4} \mathrm{Cl}$. The medium was stirred at 50-200 r.p.m. and aerated with 0.2-8 1 air $\min ^{-1}$ to maintain a dissolved oxygen concentration of $5 \pm 0.2 \mathrm{mg} \mathrm{l}^{-1}$. The temperature was $28{ }^{\circ} \mathrm{C}$ and the $\mathrm{pH}$ value was kept at $7.3\left[20 \%(\mathrm{w} / \mathrm{v}) \mathrm{Na}_{2} \mathrm{CO}_{3}\right]$. Bacteria were harvested in the late exponential growth phase at a culture density of $2 \times 10^{8} \pm 3 \times 10^{7}$ cells $\mathrm{ml}^{-1}$, concentrated by cross-flow filtration (Haemoflow HF80S, Fresenius Medical Care), and sedimented by low-speed centrifugation. The sediment was washed twice by centrifugation in mineral medium without ammonium.

Production of $\left[{ }^{14} \mathrm{C}\right]$ acetylene and ${ }^{14} \mathrm{C}$-labelled AMO. Acetylene was produced from barium carbide $\left(\mathrm{BaC}_{2}\right)$ according to Hyman \& Arp (1990) in a closed glass bottle upon addition of water, dissolved in DMSO, which was placed in a second compartment of the bottle, and stored at $-80{ }^{\circ} \mathrm{C} . \mathrm{Ba}^{14} \mathrm{C}_{2} \quad\left(108 \mathrm{mCi} \mathrm{mmol}^{-1}, 3996 \mathrm{MBq}\right.$ $\mathrm{mmol}^{-1}$; Biotrend) was composed of $\mathrm{Ba}^{14,14} \mathrm{C}_{2}, \mathrm{Ba}^{14,12} \mathrm{C}_{2}$ and $\mathrm{Ba}^{12,12} \mathrm{C}_{2}$ such that on average one carbon per $\mathrm{BaC}_{2}$ was a ${ }^{14} \mathrm{C}$ isotope. To produce $\left[{ }^{14} \mathrm{C}\right]$ acetylene, $90 \%$ unlabelled $\mathrm{BaC}_{2}$ was mixed with $10 \%{ }^{14} \mathrm{C}$-labelled $\mathrm{BaC}_{2}$. Hence, the $\left[{ }^{14} \mathrm{C}\right]$ acetylene produced was composed of about $92.5 \%\left[{ }^{12,12} \mathrm{C}\right]$ acetylene (26.04 Da), $5.0 \%$ $\left[{ }^{14,12} \mathrm{C}\right]$ acetylene $(28.04 \mathrm{Da})$ and $2.5 \%\left[{ }^{14,14} \mathrm{C}\right]$ acetylene $(30.04 \mathrm{Da})$. Throughout this paper the term $\left[{ }^{14} \mathrm{C}\right]$ acetylene is used for this mixture.

To label AMO, fresh N. europaea cells (1 g) suspended in mineral medium without ammonium $(4 \mathrm{ml})$ were transferred into a $25 \mathrm{ml}$ serum flask sealed with a butyl rubber stopper. $\mathrm{NH}_{4} \mathrm{Cl}$ was added from a $1 \mathrm{M}$ stock solution to a final concentration of $10 \mathrm{mM}$ and acetylene from $2.3 \mu \mathrm{M}\left[{ }^{14} \mathrm{C}\right]$ acetylene solution in DMSO to a final concentration of $5.8 \mathrm{nM}(63 \mu \mathrm{Ci}, 2.3 \mathrm{MBq})$. Bacteria were incubated for $1 \mathrm{~h}$ at $28{ }^{\circ} \mathrm{C}$ on a reciprocal shaker at 40 r.p.m. Labelling (inhibition) of AMO was considered complete when the nitrite concentration remained constant for $10 \mathrm{~min}$. To remove unbound acetylene, bacteria were washed five times by centrifugation in $50 \mathrm{mM}$ $\mathrm{KH}_{2} \mathrm{PO}_{4} / \mathrm{K}_{2} \mathrm{HPO}_{4}$ buffer ( $\mathrm{pH} 7.3$ ).

Electrophoresis. Protein concentration was estimated by the biuret assay (Bonner \& Laskey, 1974) after solubilizing protein in $3 \mathrm{M}$ $\mathrm{NaOH}$ for $30 \mathrm{~min}$ at $60{ }^{\circ} \mathrm{C}$ and removal of insoluble material by centrifugation (10000 $\mathrm{g}$ for $5 \mathrm{~min}$ ). BSA was employed for standardization. Denaturing PAGE (SDS-PAGE) was performed in a MiniProtean II cell vertical gel electrophoresis chamber (Bio-Rad) on $12 \%$ gels according to Laemmli (1970) at $10-30 \mathrm{~mA}$ for about $14 \mathrm{~h}$. Prior to loading, protein samples (100 $\mu$ g protein) were supplemented with an equal volume of buffer containing $125 \mathrm{mM}$ Tris/ $\mathrm{HCl}, 20 \%(\mathrm{v} / \mathrm{v})$ glycerol, $4 \%(\mathrm{w} / \mathrm{v})$ SDS, $2 \%(\mathrm{v} / \mathrm{v}) \beta$-mercaptoethanol and $0.008 \%$ (w/v) bromophenol blue. To prevent temperature-dependent aggregation of AmoA (Hyman \& Arp, 1993), samples were incubated for $10 \mathrm{~min}$ at room temperature, centrifuged $(10 \mathrm{~min}$ at $8000 \mathrm{~g}$ ) and loaded onto the gels. Molecular mass standards (Peqlab) were included on each gel to determine the apparent molecular masses of the polypeptides. Gels were stained with $0.1 \%(\mathrm{w} / \mathrm{v})$ Coomassie brilliant blue R-250 in aqueous solution with $5 \%(\mathrm{v} / \mathrm{v})$ acetic acid and $25 \%(\mathrm{v} / \mathrm{v})$ methanol. To analyse peptides smaller than $30 \mathrm{kDa}$, Tricine-SDS-PAGE was applied according to Schägger \& von Jagow (1987).

Scintillation autoradiography (fluorography) of ${ }^{14} \mathrm{C}$-labelled polypeptides. Gels stained for protein were destained, water was replaced by DMSO, and gels were soaked in 4 vols $20 \%(\mathrm{w} / \mathrm{w}) 2,5$ diphenyloxazol (PPO) in DMSO for $3 \mathrm{~h}$. PPO in the gels was crystallized by immersion in 20 vols cold water for $1 \mathrm{~h}$. Gels were then dried on Whatman filter paper (vacuum, $1 \mathrm{~h}$ at $80{ }^{\circ} \mathrm{C}$ ) and placed in an X-ray cassette with a high-performance chemoluminescence film (Hyperfilm ECL, Amersham Biosciences). The cassette was stored at $-80{ }^{\circ} \mathrm{C}$ for $10-14$ days before developing the autoradiograph.

Identification of AmoA. Polypeptides after SDS-PAGE were prepared and then analysed by MALDI-TOF mass spectrometry as described before (Schmidt et al., 2004). Polypeptides were identified via peptide mass fingerprinting (Mascot 1.7.1) with calculated $\mathrm{m} / \mathrm{z}$ values from the $N$. europaea genome database. The significance of identification was evaluated by calculating the probability-based Mowse scores (Schmidt et al., 2004).

Enzymic and chemical protein cleavage. ${ }^{14} \mathrm{C}$-labelled AmoA after Tricine-SDS-PAGE was cut from the gel and eluted in an electroeluter equipped with a dialysis membrane (cut-off $10 \mathrm{kDa}$ ) applying a buffer containing $14 \%(\mathrm{w} / \mathrm{v})$ glycine, $1 \%(\mathrm{w} / \mathrm{v})$ SDS, $0.3 \%(\mathrm{w} / \mathrm{v})$ Tris/HCl. The eluter was operated at $50 \mathrm{~mA}$ for $3.5 \mathrm{~h}$ at $4{ }^{\circ} \mathrm{C}$. The buffer was then replaced by the same buffer but without SDS and elution was continued for $2 \mathrm{~h}$. Eluted AmoA was concentrated to $1 \mathrm{mg} \mathrm{m}{ }^{-1}$ by freeze-drying and the solution was immediately digested or stored at $-80{ }^{\circ} \mathrm{C}$.

AmoA was digested with $20 \mu \mathrm{g} \mathrm{ml}^{-1}$ sequence-grade trypsin (Promega) or $30 \mu \mathrm{g} \mathrm{ml} \mathrm{m}^{-1}$ endoproteinase Pro-C (Sigma-Aldrich) for $10 \mathrm{~h}$ at room temperature. The digest was stopped by addition of $1 \mu$ l 0.1 M PMSF. Cyanogen bromide (Sigma-Aldrich) was used for AmoA cleavage according to Smith (1994). Cyanogen bromide was added in about 50-fold molar excess over the expected methionyl residues and samples were incubated for $24 \mathrm{~h}$ at room temperature. The digest was terminated by drying down under vacuum. The dried samples were resolved in Tris/ $\mathrm{HCl}$ buffer ( $\mathrm{pH}$ 7.4). Complete hydrolysis of peptides into amino acids was performed with hydrochloric acid. Peptide samples were transferred in tubes containing hydrochloric acid $(6 \mathrm{M})$ in a nitrogen atmosphere and heated to $110{ }^{\circ} \mathrm{C}$ for $24 \mathrm{~h}$. After cleavage, samples were stored at $-80{ }^{\circ} \mathrm{C}$.

Peptide and amino acid separation and identification. For Nterminal sequencing, peptides were separated by Tricine-SDS-PAGE, blotted on a PVDF membrane and the amino acid sequence was analysed by Edman degradation (analysis done by Seqlab).

To identify the amino acid composition of the trypsin-cleaved ${ }^{14} \mathrm{C}$ labelled peptide, it was further digested with cyanogen bromide, and resulting peptides were separated on a Series 900 HPLC system (Jasco) using a $250 \times 3 \mathrm{~mm}$ ReproSil-Pur ODS-3 column (Dr Maisch, Ammerbuch, Germany) and acetonitrile (ACN) in water containing $0.1 \%(\mathrm{v} / \mathrm{v})$ trifluoroacetic acid (TFA) $[10 \%(\mathrm{v} / \mathrm{v})$ ACN for $2 \mathrm{~min}$ followed by a linear gradient of $10-80 \% \mathrm{ACN}$ within $35 \mathrm{~min}$ at a flow rate of $0.4 \mathrm{ml} \mathrm{min}^{-1}$ ]. Peptides were monitored at $214 \mathrm{~nm}$ and were collected separately. The fraction containing the ${ }^{14} \mathrm{C}$-labelled peptide 
was identified by liquid scintillation counting (BETAmatic BASIC, Kontron Analytical) and then subjected to complete hydrochloric acid hydrolysis. The masses of the amino acids were analysed by liquid chromatography-electrospray ionization mass spectrometry (LC-ESI-MS) according to Eckerskorn et al. (1997). Amino acids were separated by reverse-phase HPLC using as mobile phase $5 \%(\mathrm{v} / \mathrm{v})$ ACN and $0.1 \%(\mathrm{v} / \mathrm{v})$ TFA in water followed by a linear gradient to $75 \%(\mathrm{v} / \mathrm{v})$ ACN and $0.1 \%(\mathrm{v} / \mathrm{v})$ TFA in water within 40 min (flow rate $0.5 \mathrm{ml} \mathrm{min}^{-1}$ ). Fractions corresponding to each amino acid were collected, concentrated under vacuum to dryness and resolved in methanol/water (50:50, v/v) for ESI-MS analysis. Molecular masses were determined using a Quattro-BQ triple quadrupole mass spectrometer (VG Biotech) equipped with a standard electrospray ionization source. Spectra were obtained with a capillary voltage of $3.5 \mathrm{kV}$ (source temperature $80^{\circ} \mathrm{C}$ ). The average molecular mass values were calculated from $\mathrm{m} / z$ values in the charged ion distribution profiles of the multiply charged ions (Covey et al., 1988).

\section{RESULTS AND DISCUSSION}

\section{${ }^{14} \mathrm{C}$-labelling and identification of AmoA}

$\left[{ }^{14} \mathrm{C}\right]$ Acetylene was added to ammonia-oxidizing N. europaea cells, where it selectively bound to the AmoA subunit of biologically functional AMO. ${ }^{14} \mathrm{C}$-labelled AmoA was isolated from cell protein by SDS-PAGE and analysed by fluorography (Fig. 1). As expected, one ${ }^{14} \mathrm{C}$-labelled polypeptide band was detectable with an apparent molecular mass of $27 \mathrm{kDa}$ (predicted $32 \mathrm{kDa}$, Chain et al., 2003) and the identity of the labelled polypeptide as AmoA was ascertained by MALDITOF analysis. The identification of AmoA (gi_30248947, gi_30250003) was highly significant, with a sequence coverage of $52 \%$ and an $E$-value of $6 \times 10^{-98}$.

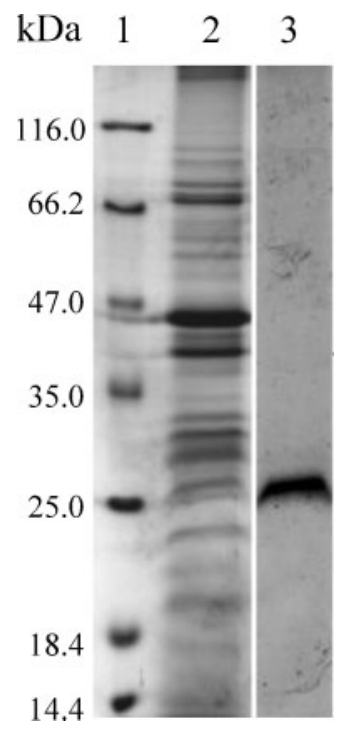

Fig. 1. SDS-PAGE stained for protein and fluorogram of $\left[{ }^{14} \mathrm{C}\right]$ acetylene-treated $N$. europaea protein. Lane 1 , protein molecular mass standards. Lane 2, Coomassie-stained protein. Lane 3 , fluorogram of lane 2 . The ${ }^{14} \mathrm{C}$-labelled polypeptide at $27 \mathrm{kDa}$ was identified as AmoA by MALDI-TOF.

\section{Identification of the $\left[{ }^{14} \mathrm{C}\right]$ acetylene-binding site in AmoA}

${ }^{14}$ C-labelled AmoA was eluted from SDS-PAGE gels and aliquots of the solution were supplemented with trypsin, Pro-C or cyanogen bromide to digest the polypeptide. The resulting peptides were separated by Tricine-SDS-PAGE (Fig. 2).

Cleavage of AmoA with trypsin or Pro-C resulted in ${ }^{14} \mathrm{C}$ labelled peptides with molecular masses of $5.6 \pm 1.1 \mathrm{kDa}$ or $2.6 \pm 0.9 \mathrm{kDa}$, respectively (Fig. 2, peptides A and B). Application of cyanogen bromide produced three labelled peptides; the strongest signal in the fluorogram originated from the smallest $4.5 \pm 1.0 \mathrm{kDa}{ }^{14} \mathrm{C}$-labelled peptide (Fig. 2, peptide C). The amount of larger ${ }^{14} \mathrm{C}$-labelled peptides increased when digestion with cyanogen bromide was performed for a shorter period of time (12 or $18 \mathrm{~h})$. Therefore, peptide $\mathrm{C}$ represents the ${ }^{14} \mathrm{C}$-labelled AmoA fragment after complete cleavage and signals at higher molecular masses originate from incompletely cleaved peptides. The observation that complete cleavage of AmoA with trypsin, Pro-C or cyanogen bromide always resulted in one ${ }^{14} \mathrm{C}$-labelled peptide provided evidence that binding of $\left[{ }^{14} \mathrm{C}\right]$ acetylene occurs at a certain part of the AmoA subunit.

Other proteases were tested for digestion of AmoA as well, but cleavage did not result in protein fragments appropriate for identification of the acetylene-binding site. Application of Asp-N, Glu-C, and Lys-C produced ${ }^{14} \mathrm{C}-$ labelled peptides of more than $10 \mathrm{kDa}$ and after cleavage with chymotrypsin the ${ }^{14} \mathrm{C}$-labelled peptide was too small to be separated by Tricine-SDS-PAGE.

The $\left[{ }^{14} \mathrm{C}\right]$ acetylene-binding peptides $\mathrm{A}$ to $\mathrm{C}$ (Fig. 2) were sequenced (Table 1 , sequences $A$ to $C$ ). As controls the same peptides, but without bound acetylene, were blotted from Tricine-SDS-PAGE and also subjected to N-terminal amino acid sequencing.

The sequences of labelled and unlabelled peptides A and B were identical, but in the ${ }^{14} \mathrm{C}$-labelled peptide C, His-191 could not be identified. The amino acid at this position had a significantly different retention time compared to histidine when analysed by HPLC during Edman degradation. In Fig. 3 the sequences of the three identified peptides are marked in the AmoA amino acid sequence. Because all three peptides were ${ }^{14} \mathrm{C}$-labelled (Fig. 2), acetylene has to be bound to a part of AmoA where the sequences of peptides $\mathrm{A}, \mathrm{B}$ and $\mathrm{C}$ overlap. The common amino acid sequence of these peptides is $\mathrm{G}_{190} \mathrm{HLYVR}$. The modified mass of His-191 and the overlapping sequences of the three peptides provided the first evidence for His-191 as the acetylene-binding site in AmoA.

\section{Identification and mass analysis of the ${ }^{14} \mathrm{C}$ - labelled amino acid in AmoA}

To prepare the ${ }^{14} \mathrm{C}$-labelled peptide with the amino acid sequence $\mathrm{G}_{190}$ HLYVR, AmoA was digested with trypsin 


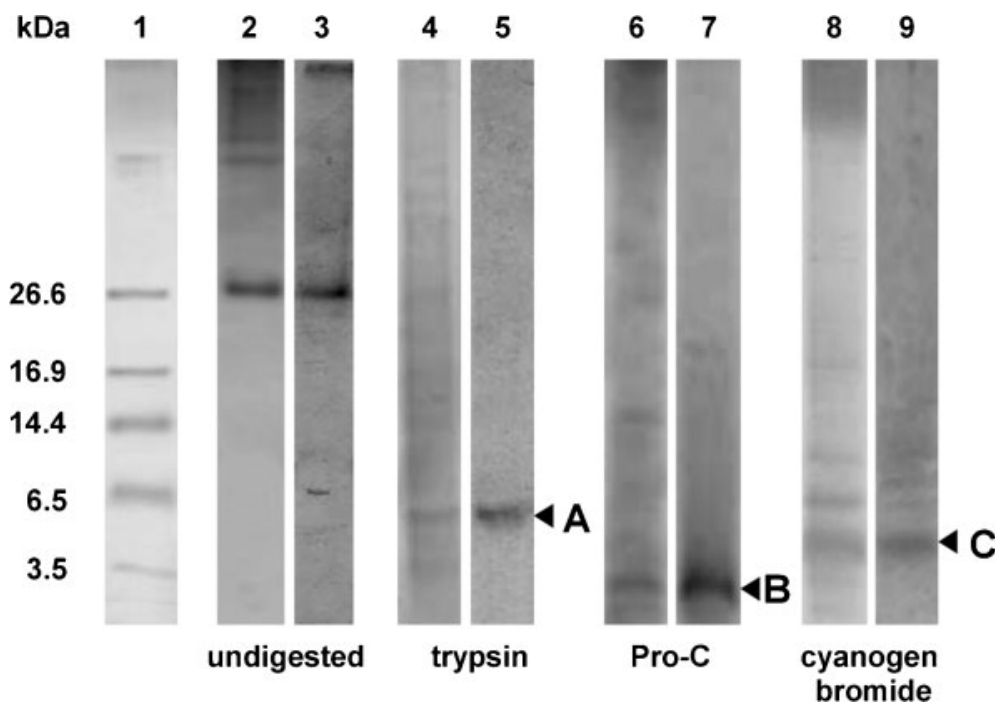

Fig. 2. Tricine-SDS-PAGE stained for protein and fluorogram of AmoA (lanes 2, 3), AmoA digested with trypsin (lanes 4, 5), Pro-C (lanes 6,7 ) or cyanogen bromide (lanes 8,9 ), and protein molecular mass standards (lane 1). Coomassie-stained protein is shown in lanes 2, 4, 6 and 8, and corresponding fluorograms in lanes 3, 5, 7 and 9. The fluorograms after trypsin or Pro-C cleavage (lanes 5,7 ) show one ${ }^{14} \mathrm{C}$-labelled peptide $(\mathrm{A}, \mathrm{B})$ and after cleavage with cyanogen bromide (lane 9 ) the smallest ${ }^{14} \mathrm{C}$-labelled peptide gave the strongest signal (C). Weaker signals at higher molecular masses (lane 9) represent ${ }^{14} \mathrm{C}$ labelled peptides after incomplete cleavage.

and cyanogen bromide. The ${ }^{14} \mathrm{C}$-labelled peptide was then purified by HPLC and subjected to complete hydrolysis with hydrochloric acid. The molecular masses of the resulting amino acids were analysed by mass spectrometry. The results are given in Table 2.

The expected molecular masses of five amino acids (Gly, Leu, Tyr, Val, Arg) of the hexapeptide were identifiable after hydrolysis, but the molecular mass of histidine (155.15 Da) was not detectable. Instead a molecular mass of 197.2 Da (molecular mass of histidine plus 42.05) was measured. The six amino acid samples were subjected to liquid scintillation counting. Only the sample containing the modified histidine was radioactive, confirming His-191 as binding site for a ${ }^{14} \mathrm{C}$-labelled acetylene derivative with a molecular mass of $42.05 \mathrm{Da}$.

The sum of the molecular masses of the six amino acids (Table 2) is $876.1 \mathrm{Da}$. Subtracting a molecular mass of $90 \mathrm{Da}\left(5 \mathrm{H}_{2} \mathrm{O}\right.$; five peptide bonds), a molecular mass of
786.1 Da has to be expected for the ${ }^{14} \mathrm{C}$-labelled hexapeptide. In fact, for the purified hexapeptide a molecular mass of 786.1 Da was measured (as well as masses of 788.1 and $790.1 \mathrm{Da}$ according to the isotope balance of the acetylene used). This result provides evidence that the treatment with hydrochloric acid hydrolysed the hexapeptide, but a further chemical modification of the amino acids including the histidine-acetylene derivative did not occur.

The histidine-acetylene derivative formed had molecular masses of 197.2, 199.2 and 201.2 Da. The sum of the molecular masses of histidine $(155.15 \mathrm{Da})$ plus $\left[{ }^{14} \mathrm{C}\right]$ acetylene $\left(\left[{ }^{12,12} \mathrm{C}\right], 26.04 ;\left[{ }^{14,12} \mathrm{C}\right], 28.04\right.$; and $\left[{ }^{14,14} \mathrm{C}\right]$, $30.04 \mathrm{Da}$ ) would be too small to explain the observed molecular mass of the histidine-acetylene derivative (Table 2). In general, monooxygenases introduce an oxygen atom into their substrate and the oxidation of acetylene by AMO obviously results in an activated acetylene derivative (intermediate) which then binds

Table 1. N-terminal sequences of ${ }^{14} \mathrm{C}$-labelled peptides after cleavage with trypsin (peptide $\mathrm{A}$ ), Pro-C (peptide B) and cyanogen bromide (peptide C)

As control, peptides without bound acetylene were sequenced. The amino acids after Edman degradation were identified by their retention time during HPLC. Lysine and leucine as well as glutamine and threonine had the same retention time and discrimination between these amino acids was not possible. The non-expected amino acids according to the AMO sequence are indicated by small letters. The subscript after the first amino acid indicates the position of the amino acid in the AmoA sequence. $\mathbf{X}$, amino acid could not be identified.

\begin{tabular}{|lll|}
\hline Peptide & Labelled with acetylene & \multicolumn{1}{c|}{ N-terminal sequence } \\
\hline A & + & $\mathrm{N}_{145}-\mathrm{W}-\mathrm{L} / \mathrm{k}-\mathrm{V}-\mathrm{T} / \mathrm{q}-\mathrm{A}-\mathrm{L} / \mathrm{k}-\mathrm{V}-\mathrm{G}-\mathrm{G}-\mathrm{G}-\mathrm{F}-\mathrm{F}-\mathrm{G}$ \\
$\mathrm{A}$ & - & $\mathrm{N}_{145}-\mathrm{W}-\mathrm{L} / \mathrm{k}-\mathrm{V}-\mathrm{T} / \mathrm{q}-\mathrm{A}-\mathrm{L} / \mathrm{k}-\mathrm{V}-\mathrm{G}-\mathrm{G}-\mathrm{G}-\mathrm{F}-\mathrm{F}-\mathrm{G}$ \\
$\mathrm{B}$ & + & $\mathrm{I}_{176} \mathrm{~V}-\mathrm{V}-\mathrm{E}-\mathrm{G}-\mathrm{T} / \mathrm{q}-\mathrm{L} / \mathrm{k}-\mathrm{L} / \mathrm{k}-\mathrm{S}-\mathrm{M}-\mathrm{A}-\mathrm{D}$ \\
$\mathrm{B}$ & - & $\mathrm{I}_{176}-\mathrm{V}-\mathrm{V}-\mathrm{E}-\mathrm{G}-\mathrm{T} / \mathrm{q}-\mathrm{L} / \mathrm{k}-\mathrm{L} / \mathrm{k}-\mathrm{S}-\mathrm{M}-\mathrm{A}-\mathrm{D}$ \\
$\mathrm{C}$ & + & $\mathrm{G}_{190}-\mathrm{X}-\mathrm{L} / \mathrm{k}-\mathrm{Y}-\mathrm{V}-\mathrm{R}-\mathrm{T} / \mathrm{q}-\mathrm{G}-\mathrm{T} / \mathrm{q}-\mathrm{P}-\mathrm{E}$ \\
C & - & $\mathrm{G}_{190}-\mathrm{H}-\mathrm{L} / \mathrm{k}-\mathrm{Y}-\mathrm{V}-\mathrm{R}-\mathrm{T} / \mathrm{q}-\mathrm{G}-\mathrm{T} / \mathrm{q}-\mathrm{P}-\mathrm{E}$ \\
\hline
\end{tabular}


(4)

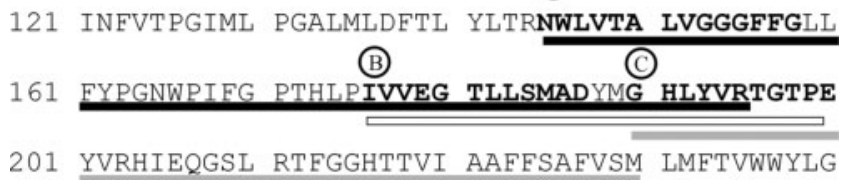

Fig. 3. Amino acid sequences of peptides after cleavage of $A m o A$ with trypsin ( $A$; peptide underlined with a black bar), Pro- $C$ ( $B$; peptide underlined with a white bar), or cyanogen bromide ( $C$; peptide underlined with a grey bar). The amino acid sequence of AmoA from amino acids 121 to 240 is diagrammed. Sequenced $\mathrm{N}$-termini are indicated with bold letters. C-termini were determined according to the cleavage characteristics of trypsin, Pro-C and cyanogen bromide. All three ${ }^{14} \mathrm{C}$-labelled peptide sequences overlap in the sequence $\mathrm{G}_{190} \mathrm{HLYVR}$, providing evidence that the $\left[{ }^{14} \mathrm{C}\right]$ acetylene-binding site is located in this hexapeptide.

covalently to His-191 of AmoA (Table 2, Fig. 3). Fomina et al. (2002) and Chan et al. (2004) suggested a mechanism for suicide inactivation of pMMO by acetylene, where acetylene reacts with an activated (reduced) copper centre initially forming a ketene, which then further reacts with a nucleophile at the active site. Histidine was proposed as suitable residue for binding ketene (Chen \& Chan, 2006; Chen et al., 2007). Due to the isotope composition of the $\left[{ }^{14} \mathrm{C}\right]$ acetylene used in this study, its oxidation to a ketene results in molecular masses of 42.04 ( $\left({ }^{12,12} \mathrm{C}\right]$ ketene $), 44.04$ $\left(\left[{ }^{14,12} \mathrm{C}\right]\right.$ ketene $)$ and $46.04\left(\left[{ }^{14,14} \mathrm{C}\right]\right.$ ketene $)$ Da. Consequently, histidine-ketene derivatives with molecular masses of 197.2, 199.2 and 201.2 Da [mass of histidine (155.15) plus $42.05,44.05$ or $46.05 \mathrm{Da}$ ] have to be expected and were in fact measured when analysing the His-191 derivative (Table 2).

Table 2. Molecular masses of amino acids in the acetylenebinding peptide $\mathrm{G}_{190} \mathrm{HLYVR}$

The hexapeptide was prepared via combined cleavage of AmoA with trypsin and cyanogen bromide and was then completely hydrolysed with hydrochloric acid. The molecular masses are listed in ascending order; the amino acids were assigned according to their molecular masses.

\begin{tabular}{|lcc|}
\hline No. & Molecular mass $(\mathbf{D a})$ & Amino acid \\
\hline 1 & $75.1 \pm 0.5$ & $\mathrm{G}$ \\
2 & $117.2 \pm 0.4$ & $\mathrm{~V}$ \\
3 & $131.2 \pm 0.3$ & $\mathrm{~L}$ \\
4 & $174.2 \pm 0.4$ & $\mathrm{R}$ \\
5 & $181.2 \pm 0.4$ & $\mathrm{Y}$ \\
$\mathbf{6}$ & $\mathbf{1 9 7 . 2} \pm 0.2$ & $?$ \\
\hline
\end{tabular}

${ }^{\star}$ In addition small amounts of molecular masses 199.2 and $201.2 \mathrm{Da}$ were detectable. According to the isotope balance of the acetylene used $\left(92.5 \% \quad\left[{ }^{12,12} \mathrm{C}\right]\right.$ acetylene, $5.0 \% \quad\left[{ }^{14,12} \mathrm{C}\right]$ acetylene and $2.5 \%$ $\left[{ }^{14,14}\right.$ C]acetylene) the proportion of the masses 197.2, 199.2 and 201.2 Da was approximately $90: 7: 3$.
The molar ratio between bound ${ }^{14} \mathrm{C}$-label and AmoA or hexapeptide, respectively, was approximately $1: 1$ (Figs 2 and 3, Table 2). $\left[{ }^{14} \mathrm{C}\right]$ Acetylene binds exclusively to AmoA, and within AmoA only the hexapeptide $\mathrm{G}_{190}$ HLYVR, and more specifically His-191, was found to be ${ }^{14} \mathrm{C}$-labelled (Table 2). After activation $\left[{ }^{14} \mathrm{C}\right]$ acetylene apparently binds specifically to His-191 and does not diffuse away from the activation site, which would result in binding at random positions and in substoichiometric amounts of ${ }^{14} \mathrm{C}$-label at the hexapeptide and at His-191. It must be assumed that His-191 is part of the acetylene-activating site in AMO or at least directly neighbours this site. It can be expected that the activation of the substrate ammonia occurs at the same active (metal) site.

\section{ACKNOWLEDGEMENTS}

This work was financially supported by the Deutsche Forschungsgemeinschaft (DFG). We thank Peter Steenbakkers, Huub op den Camp and Mike Jetten, Radboud University Nijmegen for protein identification via MALDI-TOF and Matthias Schlotter for technical assistance.

\section{REFERENCES}

Anderson, K. K. \& Hooper, A. B. (1983). $\mathrm{O}_{2}$ and $\mathrm{H}_{2} \mathrm{O}$ are each the source of one $\mathrm{O}$ in $\mathrm{NO}_{2}^{-}$produced from $\mathrm{NH}_{3}$ by Nitrosomonas; ${ }^{15} \mathrm{~N}$ NMR evidence. FEBS Lett 164, 236-240.

Bedard, C. \& Knowles, R. (1989). Physiology, biochemistry, and specific inhibitors of $\mathrm{CH}_{4}, \mathrm{NH}_{4}^{+}$, and $\mathrm{CO}$ oxidation by methanotrophs and nitrifiers. Microbiol Rev 53, 68-84.

Bonner, W. M. \& Laskey, R. A. (1974). A film detection method for tritium-labelled proteins and nucleic acids in polyacrylamide gels. Eur J Biochem 46, 83-88.

Chain, P., Lamerdin, J., Larimer, F., Regala, W., Lao, V., Land, M., Hauser, L., Hooper, A., Klotz, M. \& other authors (2003). Complete genome sequence of the ammonia-oxidizing bacterium and obligate chemolithoautotroph Nitrosomonas europaea. J Bacteriol 185, 27592773.

Chan, S. I. \& Yu, S. S. (2008). Controlled oxidation of hydrocarbons by the membrane-bound methane monooxygenase: the case for a tricopper cluster. Acc Chem Res 41, 969-979.

Chan, S. I., Chen, K. H.-C., Yu, S. S.-F., Chen, C.-L. \& Kuo, S. S.-J. (2004). Toward delineating the structure and function of the particulate methane monooxygenase from methanotrophic bacteria. Biochemistry 43, 4421-4430.

Chen, P. P. \& Chan, S. I. (2006). Theoretical modeling of the hydroxylation of methane as mediated by the particulate methane monooxygenase. J Inorg Biochem 100, 801-809.

Chen, P. P., Yang, R. B., Lee, J. C. \& Chan, S. I. (2007). Facile O-atom insertion into $\mathrm{C}-\mathrm{C}$ and $\mathrm{C}-\mathrm{H}$ bonds by a trinuclear copper complex designed to harness a singlet oxene. Proc Natl Acad Sci U S A 104, 14570-14575.

Covey, T. R., Bronner, R. F., Shushan, B. I. \& Henion, J. (1988). The determination of proteins, oligonucleotide and peptide molecular weights by ionspray mass spectrometry. Rapid Commun Mass Spectrom 2, 249-256.

Dalton, H., Wilkins, P. C. \& Jiang, Y. (1993). Mechanistic pathways in soluble methane mono-oxygenase. Biochem Soc Trans 21, 749-752. 
Dua, R. D., Bhandari, B. \& Nicholas, D. J. D. (1979). Stable isotope studies on the oxidation of ammonia to hydroxylamine by Nitrosomonas europaea. FEBS Lett 106, 401-404.

Eckerskorn, C., Strupat, K., Kellermann, J., Lottspeich, F. \& Hillenkamp, F. (1997). High-sensitivity peptide mapping by microLC with on-line membrane blotting and subsequent detection by scanning-IR-MALDI mass spectrometry. J Protein Chem 16, 349-362.

Ensign, S. A., Hyman, M. R. \& Arp, D. J. (1993). In vitro activation of ammonia monooxygenase from Nitrosomonas europaea by copper. $J$ Bacteriol 175, 1971-1980.

Fomina, L., Vazquez, B., Tkatchouk, E. \& Fomine, S. (2002). The Glaser reaction mechanism. A DFT study. Tetrahedron 58, 6741-6747.

Hooper, A. B. \& Terry, K. R. (1973). Specific inhibitor of ammonia oxidation in Nitrosomonas. J Bacteriol 115, 480-485.

Hooper, A. B., Vannelli, T., Bergmann, D. J. \& Arciero, D. M. (1997). Enzymology of the oxidation of ammonia to nitrite by bacteria. Antonie Van Leeuwenhoek 71, 59-67.

Hyman, M. R. \& Arp, D. J. (1990). The small-scale production of $\left[\mathrm{U}_{-}{ }^{14} \mathrm{C}\right]$ acetylene from $\mathrm{Ba}^{14} \mathrm{CO}_{3}$ : application to labeling of ammonia monooxygenase in autotrophic nitrifying bacteria. Anal Biochem 190, 348-353.

Hyman, M. R. \& Arp, D. J. (1992). ${ }^{14} \mathrm{C}_{2} \mathrm{H}_{2}$ - and ${ }^{14} \mathrm{CO}_{2}$-labeling studies of the de novo synthesis of polypeptides by Nitrosomonas europaea during recovery from acetylene and light inactivation of ammonia monooxygenase. J Biol Chem 267, 1534-1545.

Hyman, M. R. \& Arp, D. J. (1993). An electrophoretic study of the thermal-dependent and reductant-dependent aggregation of the 28 $\mathrm{kDa}$ component of ammonia monooxygenase from Nitrosomonas europaea. Electrophoresis 14, 619-627.

Hyman, M. R. \& Wood, P. M. (1985). Suicidal inactivation and labelling of ammonia monooxygenase by acetylene. Biochem $J$ 227, 719-725.

Hynes, R. K. \& Knowles, R. (1978). Inhibition by acetylene of ammonia oxidation in Nitrosomonas europaea. FEMS Microbiol Lett 4, 319-321.

Laemmli, U. K. (1970). Cleavage of structural proteins during the assembly of the head of bacteriophage T4. Nature 227, 680-685.

Lieberman, R. L. \& Rosenzweig, A. C. (2005a). Crystal structure of a membrane-bound metalloenzyme that catalyses the biological oxidation of methane. Nature 434, 177-182.

Lieberman, R. L. \& Rosenzweig, A. C. (2005b). The quest for the particulate methane monooxygenase active site. Dalton Trans 33903396.

Lieberman, R. L., Kondapalli, K. C., Shrestha, D. B., Hakemian, A. S., Smith, S. M., Telser, J., Kuzelka, J., Gupta, R., Borovik, A. S. \& other authors (2006). Characterization of the particulate methane monooxygenase metal centers in multiple redox states by X-ray absorption spectroscopy. Inorg Chem 45, 8372-8378.

Lipscomb, J. D. (1994). Biochemistry of the soluble methane monooxygenase. Annu Rev Microbiol 48, 371-399.

Martinho, M., Choi, D. W., Dispirito, A. A., Antholine, W. E., Semrau, J. D. \& Münck, E. (2007). Mössbauer studies of the membrane- associated methane monooxygenase from Methylococcus capsulatus Bath: evidence for a diiron center. J Am Chem Soc 129, 15783-15785.

McTavish, H., Fuchs, J. A. \& Hooper, A. B. (1993). Sequence of the gene coding for ammonia monooxygenase in Nitrosomonas europaea. J Bacteriol 175, 2436-2444.

Nesheim, J. C. \& Lipscomb, J. D. (1996). Large kinetic isotope effects in methane oxidation catalyzed by methane monooxygenase: evidence for $\mathrm{C}-\mathrm{H}$ bond cleavage in a reaction cycle intermediate. Biochemistry 35, 10240-10247.

Prior, S. D. \& Dalton, H. (1985a). Acetylene as a suicide substrate and active site probe for methane monooxygenase from Methylococcus capsulatus (Bath): inhibitor of methane-oxidising activity. FEMS Microbiol Lett 29, 105-109.

Prior, S. D. \& Dalton, H. (1985b). The effect of copper ions on membrane content and methane monooxygenase activity in methanol-grown cells of Methylococcus capsulatus (Bath). J Gen Microbiol 131, 155-163.

Rees, M. \& Nason, A. (1966). Incorporation of atmospheric oxygen into nitrite formed during ammonia oxidation by Nitrosomonas europaea. Biochim Biophys Acta 113, 398-401.

Schägger, H. \& von Jagow, G. (1987). Tricine-sodium dodecyl sulfate-polyacrylamide gel electrophoresis for the separation of proteins in the range from 1 to $100 \mathrm{kDa}$. Anal Biochem 166, 368-379.

Schmidt, I. \& Bock, E. (1997). Anaerobic ammonia oxidation with nitrogen dioxide by Nitrosomonas eutropha. Arch Microbiol 167, 106111.

Schmidt, I., Bock, E. \& Jetten, M. S. M. (2001). Ammonia oxidation by Nitrosomonas eutropha with $\mathrm{NO}_{2}$ as oxidant is not inhibited by acetylene. Microbiology 147, 2247-2253.

Schmidt, I., Steenbakkers, P. J. M., op den Camp, H. J. M., Schmidt, K. \& Jetten, M. S. M. (2004). Physiologic and proteomic evidence for a role of nitric oxide in biofilm formation by Nitrosomonas europaea and other ammonia oxidizers. J Bacteriol 186, 2781-2788.

Shears, J. H. \& Wood, P. M. (1985). Spectroscopic evidence for a photosensitive oxygenated state of ammonia monoxygenase. Biochem J 226, 499-507.

Smith, B. J. (1994). Chemical cleavage of proteins. In Basic Protein and Peptide Protocols. Methods in Molecular Biology, vol. 32, pp. 297309. Edited by J. M. Walker. Totowa, NJ: Humana Press.

Stirling, D. I. \& Dalton, H. (1977). Effect of metal-binding agents and other compounds on methane oxidation by two strains of Methylococcus capsulatus. Arch Microbiol 114, 71-76.

Yeager, C. M., Bottomley, P. J., Arp, D. J. \& Hyman, M. R. (1999). Inactivation of toluene 2-monooxygenase in Burkholderia cepacia G4 by alkynes. Appl Environ Microbiol 65, 632-639.

Zahn, J. A. \& DiSpirito, A. A. (1996). Membrane-associated methane monooxygenase from Methylococcus capsulatus (Bath). J Bacteriol 178, 1018-1029.

Zahn, J. A., Arciero, D. M., Hooper, A. B. \& DiSpirito, A. A. (1996). Evidence for an iron center in the ammonia monooxygenase from Nitrosomonas europaea. FEBS Lett 397, 35-38.

Edited by: D. J. Arp 